\title{
Gender-Dependent Expression of Leading and Passenger Strand of miR-21 and miR-16 in Human Colorectal Cancer and Adjacent Colonic Tissues
}

\author{
K. HASÁKOVÁ ${ }^{1}$, J. BEZAKOVA ${ }^{1}$, M. VICIAN ${ }^{2}$, R. REIS $^{3}$, M. ZEMAN $^{1}$, I. HERICHOVA $^{1}$ \\ ${ }^{1}$ Department of Animal Physiology and Ethology, Faculty of Natural Sciences, Comenius \\ University, Bratislava, Slovak Republic, ${ }^{2}$ Fourth Surgery Department, University Hospital, \\ Comenius University Bratislava, Bratislava, Slovak Republic, ${ }^{3}$ First Surgery Department, \\ University Hospital, Comenius University Bratislava, Bratislava, Slovak Republic
}

Received March 16, 2017

Accepted November 8, 2017

\section{Summary}

miRNAs are small regulatory RNA molecules involved in posttranscriptional gene silencing. Their biosynthesis results in the formation of duplex consisting of a leading and a passenger strand of mature miRNA. The leading strand exhibits the main activity but recent findings indicate a certain role of the passenger strand as well. Deregulated levels of miRNA were found in many types of cancers including colorectal cancer. miR-21 and miR-16 were indicated as possible markers of colorectal cancer, however, small attention to gender differences in their expression was paid so far. Therefore, the aim of our study was to investigate the expression of miR-21-5p, miR-21-3p, miR-16-5p and miR-16-3p in human colorectal cancer tissue and compare it to the adjacent tissues taken during surgery in men and women separately. Our results showed an up-regulation of all measured miRNAs in tumor tissue compared to adjacent tissues. As expected, tumors and adjacent tissues exhibited a significantly higher expression of leading miRNAs compared to passenger strand of miR-21 and miR-16. The expression of leading and passenger strand of miR-21 and miR-16 positively correlated exhibiting the highest correlation coefficient in the distal tissue. The expression pattern showed gender-dependent differences, with higher levels of miRNA in men than in women. Our findings indicate a gender-related expression pattern of miRNA, which should be considered as an important factor in generating new prognostic or diagnostic biomarkers.

\section{Key words}

Carcinoma • miR-21-5p • miR-21-3p • miR-16-5p • miR-16-3p • Biomarker

\section{Corresponding author}

I. Herichova, Department of Animal Physiology and Ethology, Faculty of Natural Sciences, Comenius University Bratislava, Ilkovicova 6, 84215 Bratislava, Slovak Republic. E-mail: herichova1@uniba.sk

\section{Introduction}

MicroRNAs (miRNAs) are short (17-25 nucleotides), single-stranded RNA molecules that belong to a family of small non-coding regulatory RNAs. Their function relies on translation repression or degradation of target mRNA sequences. Specific regulation is based on high complementarity between 2-8 nucleotides called seed sequence and 3' untranslated region (3'UTR) of target genes. According to genome analysis of 3 'UTRs, it has been estimated that more than $60 \%$ of all human protein coding genes are regulated by miRNAs (Friedman et al. 2009, Voglova et al. 2016).

Biogenesis of miRNA is a complex process that includes the processing of primary miRNA in the nucleus by RNase Drosha into precursor miRNA (pre-miRNA) and subsequent transport into the cytoplasm where pre-miRNA is cleaved by another RNase Dicer and forms a mature duplex (Treiber et al. 2012). After maturation, it is necessary to unwind the miRNA duplex and separate each strand. Strand that exerts higher levels is called a leading or guide strand. The fate of the other strand, called the passenger strand, is not fully understood. In contrast to siRNAs, which typically undergo 
an immediate cleavage of the passenger strand in order to liberate the leading strand (Matranga et al. 2005), miRNA duplexes at least partially omit this step and the co-existence and functionality of both miRNA strands has been reported frequently (Choo et al. 2014). Some authors suggest a tissue-dependent mechanism of strand selection. While in some tissues a passenger strand is subjected to degradation, in others it can be accumulated and biologically active (Ro et al. 2007).

miRNAs have the capacity to modulate many cellular pathways, including cell proliferation, differentiation and survival or apoptosis, which are frequently deregulated in the tumor cells. In fact, changes in miRNA levels were reported in a variety of human cancers, including colorectal cancer (CRC) (Bandrés et al. 2006, Slaby et al. 2007).

Colorectal cancer is the third most commonly diagnosed cancer in males and the second in females, with an increasing level of incidence and mortality mainly in middle-East Europe and South America (Torre et al. 2015). The process of CRC development consists of a multistep pathway that involves the deregulation of many oncogenes and tumor suppressors including miRNAs (Vogelstein et al. 1988, Nagel et al. 2008, Johnson et al. 2005).

Changes in miR-21-5p expression are clearly associated with CRC and other types of cancers. Several groups reported up-regulated miR-21-5p expression in $\mathrm{CRC}$ tumor tissue or in cancer cells. The high expression of miR-21-5p correlates with the clinical stage, lymph node metastasis and distant metastasis presence (Faltejskova et al. 2012, Dong et al. 2014). miR-21 was confirmed to target several tumor suppressor genes in CRC cells, including pdcd4 (Asangani et al. 2008), tiam1 (Cottonham et al. 2010) or spry (Sayed et al. 2008). Post-transcriptional suppression of these genes induces cell proliferation and migration, invasion activity and the forming of metastasis.

miR-16 was suggested by some authors as a miRNA suitable for the normalization of miRNA measurement (Peltier and Latham 2008, Song et al. 2012, Zhu et al. 2012), but recent evidences indicate its role in tumorigenesis. miR-16 was identified as a negative regulator of multiple oncogenes e.g. $k$-ras in colorectal cancer (You et al. 2016), oncogene Wipl in mammary cells (Zhang et al. 2010) and apoptosis suppressor FEAT in a variety of cancer cells (Liang et al. 2015). miR-16 was implicated as a possible marker of the colorectal cancer (Diamantopoulos et al. 2017).
Despite the existence of many studies that focus on the expression and role of the leading strand of miR-21 and miR-16 in CRC, little is known about the expression pattern of their passenger strands. Moreover, small attention to gender differences in miR-21 and miR-16 expression was paid so far. Therefore, the aim of our study was to investigate the expression of leading and passenger strand of miR-21 and miR-16 in human colorectal cancer tissue and compare it to the healthy adjacent tissues in male and female patients separately.

\section{Methods}

The study includes 53 patients of both genders undergoing surgery for CRC (27 males and 26 females, average age 68 ranging from 47-86 years). All patients were exposed to a standard hospital practice with lights on from 6:00 a.m. to 9:00 p.m. (The First Surgery Department, University Hospital, Comenius University, Bratislava). The experimental protocol was explained to each patient and informed consent was obtained. The experimental protocol was approved by the Ethics Committee. Histopathological examinations were performed by a hospital pathologist. Tissue samples taken during the surgery were collected from the tumor as well as from the proximal ( $\geq 10 \mathrm{~cm}$ above the tumor) and distal ( $\geq 2 \mathrm{~cm}$ under the tumor) parts of the resected colon. The surgery was conducted between 10:00 a.m. and 1:00 p.m. Tissue samples were collected into liquid nitrogen and then stored at $-80{ }^{\circ} \mathrm{C}$ until further processing. Details about the characteristics of the patients included in the study are listed in Table 1.

Mature miRNA was extracted from the tissue samples using RNAzol (MRC, USA) according to the manufacturer's instructions. cDNA was synthesized with miScript II RT (Qiagen, Germany). Detection of relative miRNA expression was performed by real-time PCR with the MiniScript SYBR Green PCR Kit (Qiagen, Germany) and the StepOnePlus TM Real-Time PCR Systems (Applied Biosystems, USA) using universal primer miScript Universal Primer (Qiagen, Germany) and specific primers with the following sequences: miR-21-5p 5'-TAGCTTATCAGACTGATGTTGA-3', miR-21-3p 5'-CAACACCAGTCGATGGGCTGT-3', miR-16-5p 5'-TAGCAGCACGTAAATATTGGCG-3', miR-16-3p 5'-CCAGTATTAACTGTGCTGCTGA-3'. The $20 \mu \mathrm{l}$ PCR reaction mixture included $0.06 \mu \mathrm{l}$ of $\mathrm{RT}$ product. Reactions were incubated at $95{ }^{\circ} \mathrm{C}$ for $15 \mathrm{~min}$, followed by $35-45$ cycles: $94{ }^{\circ} \mathrm{C}$ for $15 \mathrm{~s}, 55^{\circ} \mathrm{C}$ for $30 \mathrm{~s}$ 
and $70{ }^{\circ} \mathrm{C}$ for $30 \mathrm{~s}$. The specificity of value) at 35 cycles was set as assay sensitivity. Relative PCR reaction was validated by melting curve analysis. The expression of $U 6$ was used as a normalization control of gene expression, with the following sequences: sense 5'-GCTTCGGCAGCACATATACTAA-3', antisense 5'-AAAATATGGAACGCTTCACGA-3'. Ct (threshold standard curve method was used to calculate relative miRNA concentration. Calibration curve was prepared from the sample with the high concentration of measured miRNA.

Table 1. Association of miRNAs expression with clinicopathological features, age and gender of patients with colorectal cancer.

\begin{tabular}{|c|c|c|c|c|c|c|c|c|c|}
\hline & \multirow{2}{*}{$\begin{array}{c}\text { Number } \\
(\%)\end{array}$} & \multicolumn{2}{|c|}{ miR-21-5p } & \multicolumn{2}{|c|}{ miR-21-3p } & \multicolumn{2}{|c|}{ miR-16-5p } & \multicolumn{2}{|c|}{ miR-16-3p } \\
\hline & & Mean \pm SEM & $\mathrm{P}$ & Mean \pm SEM & $\mathrm{P}$ & Mean \pm SEM & $\mathrm{P}$ & Mean \pm SEM & $\mathrm{P}$ \\
\hline \multicolumn{10}{|l|}{ Gender } \\
\hline Male & $27(51)$ & $39.06 \pm 11.13$ & \multirow{2}{*}{0.024} & $37.42 \pm 19.58$ & \multirow{2}{*}{0.004} & $28.88 \pm 13.74$ & \multirow{2}{*}{0.067} & $29.01 \pm 16.32$ & \multirow{2}{*}{0.04} \\
\hline Female & $26(49)$ & $9.66 \pm 2.31$ & & $5.11 \pm 2.61$ & & $6.77 \pm 2.22$ & & $7.54 \pm 3.21$ & \\
\hline
\end{tabular}

Histological grade

\begin{tabular}{llcccccc}
\hline $\mathrm{G}<2$ & $11(21)$ & $40.74 \pm 21.63$ & & $58.62 \pm 43.15$ & & $39.82 \pm 30.44$ & $53.73 \pm 41.95$ \\
$\mathrm{G} \geq 2$ & $42(79)$ & $19.95 \pm 5.25$ & & $10.73 \pm 3.91$ & ns & $12.30 \pm 4.44$ & ns \\
\hline
\end{tabular}

\section{Clinical stage}

\begin{tabular}{lcccccccc}
\hline I-II & $26(49)$ & $33.81 \pm 11.34$ & & $35.24 \pm 19.68$ & & $26.79 \pm 14.13$ & & $30.15 \pm 18.45$ \\
III-IV & $27(51)$ & $15.12 \pm 4.41$ & & $7.29 \pm 2.91$ & & $9.56 \pm 3.52$ & ns & $9.01 \pm 3.04$ \\
\hline
\end{tabular}

T (tumor invasion)

\begin{tabular}{lccccccc}
\hline T1-T2 & $4(8)$ & $18.06 \pm 6.51$ & & $12.06 \pm 6.64$ & & $15.81 \pm 8.36$ & $n$ \\
T3-T4 & $49(92)$ & $24.78 \pm 6.51$ & ns & $22.07 \pm 10.91$ & ns & $18.19 \pm 7.76$ & $19.19 \pm 9.61$ \\
\hline
\end{tabular}

\section{N (nodal status)}

\begin{tabular}{lcccccccc}
\hline N0 & $27(51)$ & $32.55 \pm 11.13$ & & $33.89 \pm 18.95$ & & $25.80 \pm 13.64$ & $28.90 \pm 17.71$ \\
N1-2 & $26(49)$ & $15.75 \pm 4.41$ & & $7.59 \pm 3.02$ & ns & $9.93 \pm 3.64$ & $9.37 \pm 3.14$ \\
\hline
\end{tabular}

M (distant metastasis)

\begin{tabular}{lllcccccc}
\hline M0 & $40(75)$ & $25.83 \pm 7.77$ & & $24.44 \pm 13.10$ & ns & $20.32 \pm 9.31$ & $21.41 \pm 11.59$ \\
M1 & $13(25)$ & $19.53 \pm 8.19$ & & $11.23 \pm 5.70$ & & $10.92 \pm 6.33$ & $11.32 \pm 5.47$ \\
\hline
\end{tabular}

Tumor localization

\begin{tabular}{|c|c|c|c|c|c|c|c|c|c|}
\hline C18 (colon) & $31(59)$ & $23.10 \pm 8.40$ & \multirow{3}{*}{$\mathrm{ns}$} & $25.52 \pm 15.52$ & \multirow{3}{*}{ ns } & $25.06 \pm 12.06$ & \multirow{3}{*}{$\mathrm{ns}$} & $25.97 \pm 15.18$ & \multirow{3}{*}{$\mathrm{ns}$} \\
\hline $\begin{array}{l}\text { C19 (rectosigmoid } \\
\text { junction) }\end{array}$ & 7 (13) & $22.47 \pm 12.18$ & & $6.26 \pm 3.91$ & & $6.70 \pm 3.40$ & & $6.02 \pm 3.27$ & \\
\hline C20 (rectum) & $15(28)$ & $27.93 \pm 12.18$ & & $18.07 \pm 11.48$ & & $8.72 \pm 3.71$ & & $11.32 \pm 5.68$ & \\
\hline \multicolumn{10}{|l|}{ Age } \\
\hline$\leq 68$ & $26(49)$ & $15.12 \pm 5.04$ & \multirow{2}{*}{0.040} & $7.14 \pm 3.06$ & \multirow{2}{*}{ ns } & $8.18 \pm 3.58$ & \multirow{2}{*}{0.025} & $7.41 \pm 2.62$ & \multirow{2}{*}{$\mathrm{ns}$} \\
\hline$>68$ & $27(51)$ & $33.18 \pm 10.71$ & & $33.30 \pm 18.25$ & & $27.48 \pm 13.57$ & & $29.13 \pm 16.38$ & \\
\hline
\end{tabular}

miRNAs expression is given in arbitrary units. Statistical evaluation was performed by Mann-Whitney U-test in all cases except of expression related to tumor localization that was evaluated by Kruskal-Wallis analysis; P - statistical difference between groups, ns - non significant. 


\section{Statistical analysis}

The Kruskal-Wallis analysis of variance and post hoc test - Dunn's multiple comparisons test - were used for evaluation of differences between tumor, proximal and distal tissues. Mann-Whitney $U$-test was used for the determination of gender differences in miRNA expression. Linear regression analysis was used to determine the correlation between leading and passenger strands of miR-21 and miR-16.

\section{Results}

Summary of relationships between expression of studied miRNAs in colorectal cancer tissue and clinicopathological features, age and gender of patients is given in Table 1. Expression of leading strand miR-21 and miR-16 was significantly higher in older patients with the age above 68 compared to younger patients
$(\mathrm{P}<0.05$, Mann-Whitney $U$-test, Table 1).

Expression of leading strand of miR-21 and miR-16 was several thousand times higher in comparison with expression of passenger strand. Ct values of samples measured with the same dilution were as follows: tumormiR-21-5p Ct 16 \pm 0.6 , miR-21-3p Ct 29 \pm 0.4 ; proximal tissue - miR-21-5p Ct 23 \pm 0.5 , miR-21-3p Ct 33 \pm 0.5 ; distal tissue - miR-21-5p Ct 22 \pm 0.6 , miR-21-3p Ct $32 \pm 0.4$ and tumor - miR-16-5p Ct $21 \pm 0.5$, miR-16-3p

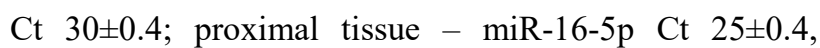
miR-16-3p Ct 34 \pm 0.5 ; distal tissue - miR-16-5p Ct $25 \pm 0.5$, miR-16-3p Ct $34 \pm 0.4$.

Expression of miR-21-5p, miR-21-3p, miR-16-5p and miR-16-3p showed significant up-regulated levels in tumor tissue compared to both adjacent proximal and distal tissues $(\mathrm{P}<0.001$, KruskalWallis, Fig. 1A).
A $\quad$ miR-21-5p
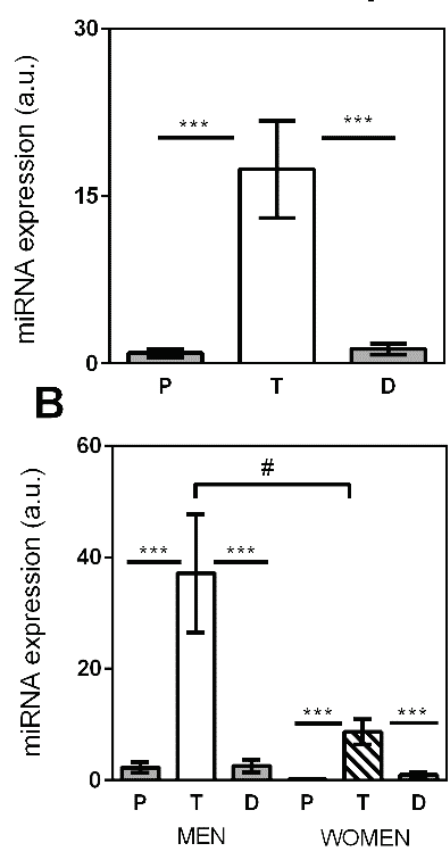

miR-21-3p
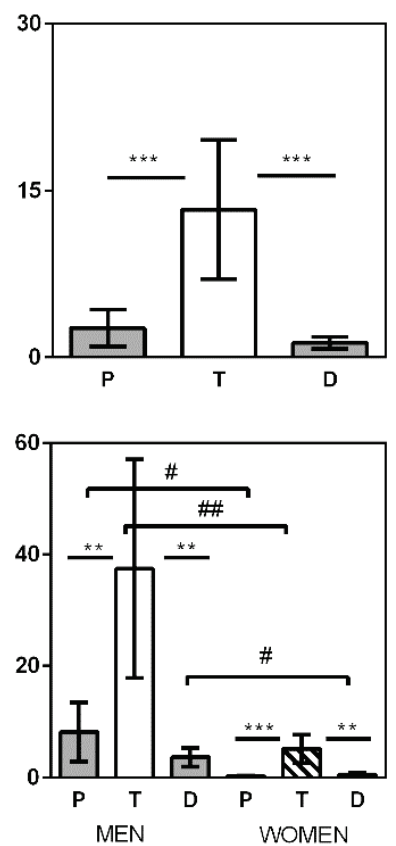

$\operatorname{miR}-16-5 p$
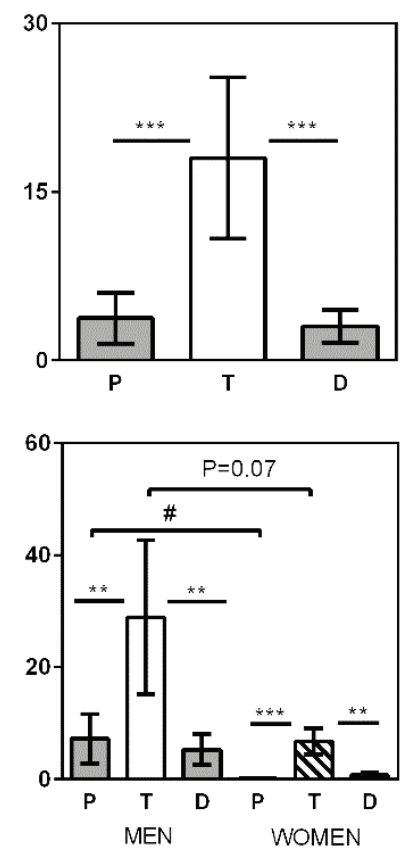

miR-16-3p
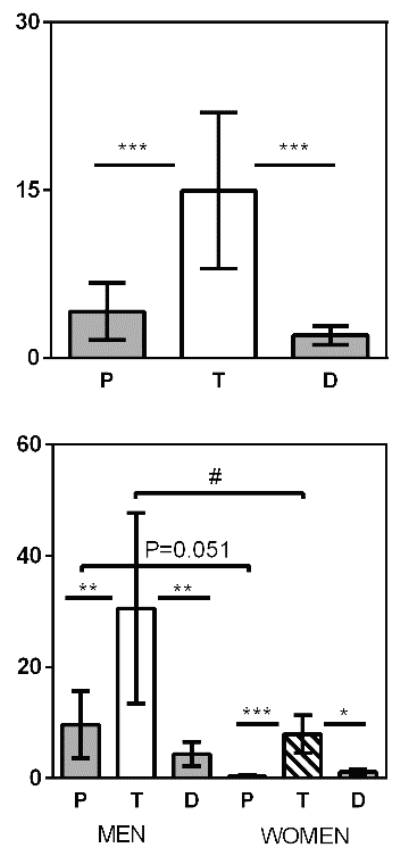

Fig. 1. Expression of leading and passenger strands of miR-21 and miR-16 in tumor and adjacent proximal and distal tissues of all patients (A). Gender-dependent differences in miRNAs expression in tumor and adjacent tissues (B). Values are presented as arithmetic means \pm SEM. $\mathrm{P}$ - proximal tissue, $\mathrm{T}$ - tumor tissue, $\mathrm{D}-$ distal tissue, $* \mathrm{P}<0.05, * * \mathrm{P}<0.01, * * * \mathrm{P}<0.001$ Kruskal-Wallis analysis; ${ }^{\#} \mathrm{P}<0.05,{ }^{\# \#} \mathrm{P}<0.01$, Mann-Whitney U-test; a.u. - arbitrary units.

After dividing patients according to the gender, differences in miR-21-5p, miR-21-3p, miR-16-5p and miR-16-3p expression between men and women in tumor and adjacent tissue were observed as well (KruskalWallis, Fig. 1B). Men showed a significantly higher expression of miR-21-5p, miR-21-3p and miR-16-3p in tumor tissue than women $(\mathrm{P}<0.05$, Mann-Whitney $U$-test, Fig. 1B). The same pattern in miR-21-3p and miR-16-5p expression was preserved in proximal non-tumor tissue with significant up-regulation in men compared to women $(\mathrm{P}<0.05$, Mann-Whitney $U$-test, Fig. $1 \mathrm{~B})$. In the distal tissue a significant difference between men and 
women was observed in miR-21-3p expression $(\mathrm{P}<0.05$, Mann-Whitney $U$-test, Fig. 1B).

Expression of leading and passenger strand of miR-21 and miR-16 positively correlated in all analyzed tissues. Correlation equations and coefficients of leading and passenger strand of miR-21 were as follows: in tumor $\mathrm{y}=57.09 \mathrm{x}-345.32 \quad(\mathrm{R}=0.755, \mathrm{P}<0.0001)$, in the distal tissue $y=57.804 x-9.246(R=0.836, P<0.0001)$ and in the proximal tissue $\mathrm{y}=119.54 \mathrm{x}+5.4517(\mathrm{R}=0.613, \mathrm{P}<0.0001)$. Correlation equations and coefficients of leading and passenger strand of miR-16 were as follows: in tumor $\mathrm{y}=0.4876 \mathrm{x}-2.5658 \quad(\mathrm{R}=0.893, \mathrm{P}<0.0001)$, in the distal tissue $y=0.3716 x+1.2948(R=0.950, P<0.0001)$ and in the proximal tissue $\mathrm{y}=0.6258 \mathrm{x}-0.695(\mathrm{R}=0.933, \mathrm{P}<0.0001$; in all cases linear regression analysis was used, data are not shown). Expression of miR-21 and miR-16 leading and passenger strand showed the highest correlation in the distal tissue.

\section{Discussion}

Our study clearly demonstrated genderdependent differences in miR-21-5p and miR-16-5p expression. There is a strong implication that miR-21-5p and miR-16-5p are expressed more in men compared to women. The study was also focused on differences in the leading and passenger strand of miR-21 and miR-16 that also showed gender-dependent regulation of expression.

We confirmed previous results describing significantly up-regulated expression of miR-21-5p in CRC human tissue samples (Slaby et al. 2007, Dong et al. 2014). In situ hybridization assay on formalin-fixed paraffin embedded tissue samples revealed that miR-21 is predominantly expressed in stromal parts of colorectal cancer tumours. High expression of miR-21 in stage II colon cancer patient group correlated with shorter disease-free survival and miR-21 expression was found higher in male than in female patients (Nielsen et al. 2011). This finding is supported by the present study.

Expression analysis of the passenger strand miR-21-3p in CRC tissue and adjacent tissues revealed high correlation with the leading strand miR-21-5p despite lower levels of miR-21-3p expression compared to miR-21-5p in all analyzed tissues. Our results are in agreement with studies that identified co-expression and cross-targeting of several miRNAs $5 p$ and $3 p$ strands, including miR-21 in colon cancer cells (Choo et al. 2014). Passenger strand miR-21-3p has been studied mainly in ovarian cancer cells. miR-21-3p was shown to mediate processes leading to ovarian cancer resistance to chemotherapeutics. High levels of miR-21-3p increase cisplatin resistance by targeting NAV3 (Pink et al. 2015). Higher expression of miR-21-5p compared to miR-21-3p was identified on a panel of cancer cell lines and inhibition of miR-21-5p or miR-21-3p resulted in a significant decrease in ovarian and prostate cancer cell proliferation and invasion (Baéz-Vega et al. 2016). Overexpression of miR-21-3p but not leading strand miR-21-5p activates, by an unknown mechanism, the transcription of L1CAM expression in renal-, endometrial- and ovarian carcinoma-derived cell lines. L1CAM is a molecule that promotes cell motility, invasion and metastasis formation and it is frequently expressed in different types of human cancers and is associated with poor prognosis (Doberstein et al. 2014). Our findings indicate gender dependent regulation of miR-21-3p expression that was not studied previously.

We determined up-regulated levels of both strands of miR-16 in CRC tissue when comparing with healthy adjacent tissues. Similar results were observed by Diamantopoulos et al. (2017) who reported a significant up-regulation of miR-16 in CRC tissue compared to adjacent tissue in a study involving 182 patients. A higher expression of miR-16 was associated with a worse survival rate of patients. On the other hand, there are results reporting down-regulation of miR-16 in CRC tissue compared to the adjacent tissue (Qian et al. 2013, Xiao et al. 2014). Down-regulated levels of miR-16 in CRC tissue were associated with advanced TNM stage and a poor histological grading stage. Moreover, low levels of miR-16 together with miR-15a better correlate with survival rates than those of miR-15a or miR-16 expression alone (Xiao et al. 2014).

There is also uncertainty in studies describing miR-16 expression in other types of cancers. Expression of miR-16 in ovarian cancer tissue was found to be down-regulated (Bhattacharya et al. 2009). On the other hand, up-regulated expression of miR-16 in ovarian cancer compared to non-cancerous tissues has been reported. Expression of miR-16 significantly positively correlated with $\mathrm{CDC} 25 \mathrm{C}$, a critical molecule that triggers entry to mitosis (Miles et al. 2012). The serum level of miR-16 in ovarian patients and control patients were similar and did not show any difference (Meng et al. 2015).

Our results indicate gender-related differences that may be responsible for the variability frequently reported in miRNA measurements. Male patients 
exhibited significantly higher expression of miR-21-5p, miR-21-3p and miR-16-3p in colorectal cancer tissue when compared with female patients. The same results were observed in non-tumor proximal tissue in miR-21-3p and miR-16-5p measurements. Taken together, according to our results expression of miRNAs in tumor and non-tumor tissues is higher in male patients compared to female patients.

Gender differences in miRNA expression were reported in several diseases, mostly in those with some gender-related predisposition. Regulation of miRNA may be influenced by gender-dependent factors, such as sex steroid hormones or X-linked genes. In particular, estrogen nuclear receptors regulate the biogenesis of specific miRNA - miR-30a by inhibiting pri-miRNA synthesis, or promoting miR-23b, miR-27b and miR-24-1 accumulation in breast cancer cells (Paris et al. 2012). The lupus-associated miRNA- cluster miR-182, miR-31 and miR-148a was found overexpressed in the splenocytes derived from female mice (Dai et al. 2013). A study that focused on the analysis of female and male familial breast cancer tissues identified significantly up-regulated levels of miR-152 and miR-497 in male breast cancer compared to female (Pinto et al. 2014). The expression profile of serum miRNAs in healthy human men and women subjects revealed that 90 miRNAs were present both in women's and men's serum, while 10 and 1 miRNAs were expressed only in men and women subjects, respectively. Men's serum-specific miRNAs were miR-100, miR-184 and miR-923 while women's serum-specific miRNA was miR-222 (Chen et al. 2008).

To conclude, we provide evidence supporting gender-specific expression of miRNAs in human colorectal cancer tissue. Our results implicate that the gender-related expression pattern of miRNAs should be considered as an important factor in generating new prognostic or diagnostic biomarkers and the role of both strands of miRNAs should be investigated.

\section{Conflict of Interest}

There is no conflict of interest.

\section{Acknowledgements}

Supported by grants VEGA 1/0499/15, APVV-14-0318, APVV-16-0209 and UK/137/17.

\section{References}

ASANGANI IA, RASHEED SA, NIKOLOVA DA, LEUPOLD JH, COLBURN NH, POST S, ALLGAYER H: MicroRNA-21 (miR-21) post-transcriptionally downregulates tumor suppressor Pdcd4 and stimulates invasion, intravasation and metastasis in colorectal cancer. Oncogene 27: 2128-2136, 2008.

BÁEZ-VEGA PM, ECHEVARRÍA VARGAS IM, VALIYEVA F, ENCARNACIÓN-ROSADO J, ROMAN A, FLORES J, MARCOS-MARTÍNEZ MJ, VIVAS-MEJÍA PE: Targeting miR-21-3p inhibits proliferation and invasion of ovarian cancer cells. Oncotarget 7: 36321-36337, 2016.

BANDRÉS E, CUBEDO E, AGIRRE X, MALUMBRES R, ZARATE R, RAMIREZ N, ABAJO A, NAVARRO A, MORENO I, MONZO M, GARCIA-FONCILLAS J: Identification by real-time PCR of 13 mature microRNAs differentially expressed in colorectal cancer and non-tumoral tissues. Mol Cancer 5: 29, 2006.

BHATTACHARYA R, NICOLOSO M, ARVIZO R, WANG E, CORTEZ A, ROSSI S, CALIN GA, MUKHERJEE P: MiR-15a and MiR-16 control Bmi-1 expression in ovarian cancer. Cancer Res 69: 9090-9095, 2009.

CHEN X, BA Y, MA L, CAI X, YIN Y, WANG K, GUO J, ZHANG Y, CHEN J, GUO X, ET AL.: Characterization of microRNAs in serum: a novel class of biomarkers for diagnosis of cancer and other diseases. Cell Res 18 : 997-1006, 2008.

CHOO KB, SOON YL, NGUYEN PN, HIEW MS, HUANG CJ: MicroRNA-5p and -3p co-expression and cross-targeting in colon cancer cells. J Biomed Sci 21: 95, 2014.

COTTONHAM CL, KANEKO S, XU L: miR-21 and miR-31 converge on TIAM1 to regulate migration and invasion of colon carcinoma cells. $J$ Biol Chem 285: 35293-35302, 2010.

DAI R, MCREYNOLDS S, LEROITH T, HEID B, LIANG Z, AHMED SA: Sex differences in the expression of lupus-associated miRNAs in splenocytes from lupus-prone NZB/WF1 mice. Biol Sex Differ 4: 19, 2013.

DIAMANTOPOULOS MA, KONTOS CK, KERIMIS D, PAPADOPOULOS IN, SCORILAS A: Upregulated miR-16 expression is an independent indicator of relapse and poor overall survival of colorectal adenocarcinoma patients. Clin Chem Lab Med 55: 737-747, 2017. 
DOBERSTEIN K, BRETZ NP, SCHIRMER U, FIEGL H, BLAHETA R, BREUNIG C, MÜLLER-HOLZNER E, REIMER D, ZEIMET AG, ALTEVOGT P: miR-21-3p is a positive regulator of L1CAM in several human carcinomas. Cancer Lett 354: 455-466, 2014.

DONG Y, YU J, NG SS: MicroRNA dysregulation as a prognostic biomarker in colorectal cancer. Cancer Manag Res 14: 405-422, 2014.

FALTEJSKOVA P, BESSE A, SEVCIKOVA S, KUBICZKOVA L, SVOBODA M, SMARDA J, KISS I, VYZULA R, SLABY O: Clinical correlations of miR-21 expression in colorectal cancer patients and effects of its inhibition on DLD1 colon cancer cells. Int J Colorectal Dis 27: 1401-1408, 2012.

FRIEDMAN RC, FARH KK, BURGE CB, BARTEL DP: Most mammalian mRNAs are conserved targets of microRNAs. Genome Res 19: 92-105, 2009.

JOHNSON SM, GROSSHANS H, SHINGARA J, BYROM M, JARVIS R, CHENG A, LABOURIER, E, REINERT KL, BROWN D, SLACK FJ: RAS is regulated by the let-7 microRNA family. Cell 120: 635-647, 2005.

LIANG H, FU Z, JIANG X, WANG N, WANG F, WANG X, ZHANG S, WANG Y, YAN X, GUAN WX, ET AL.: miR-16 promotes the apoptosis of human cancer cells by targeting FEAT. BMC Cancer 15: 448, 2015.

MATRANGA C, TOMARI Y, SHIN C, BARTEL DP, ZAMORE PD: Passenger-strand cleavage facilitates assembly of siRNA into Ago2-containing RNAi enzyme complexes. Cell 123: 607-620, 2005.

MENG X, JOOSSE SA, MÜLLER V, TRILLSCH F, MILDE-LANGOSCH K, MAHNER S, GEFFKEN M, PANTEL K, SCHWARZENBACH H: Diagnostic and prognostic potential of serum miR-7, miR-16, miR-25, miR-93, miR-182, miR-376a and miR-429 in ovarian cancer patients. Br J Cancer 113: 1358-1366, 2015.

MILES GD, SEILER M, RODRIGUEZ L, RAJAGOPAL G, BHANOT G: Identifying microRNA/mRNA dysregulations in ovarian cancer. BMC Res Notes 5: 164, 2012.

NAGEL R, LE SAGE C, DIOSDADO B, VAN DER WAAL M, OUDE VRIELINK JA, BOLIJN A, MEIJER GA, AGAMI R: Regulation of the adenomatous polyposis coli gene by the miR-135 family in colorectal cancer. Cancer Res 68: 5795-5802, 2008.

NIELSEN BS, JØRGENSEN S, FOG JU, SØKILDE R, CHRISTENSEN IJ, HANSEN U, BRÜNNER N, BAKER A, MØLLER S, NIELSEN HJ: High levels of microRNA-21 in the stroma of colorectal cancers predict short disease-free survival in stage II colon cancer patients. Clin Exp Metastasis 28: 27-38, 2011.

PARIS O, FERRARO L, GROBER OM, RAVO M, DE FILIPPO MR, GIURATO G, NASSA G, TARALLO R, CANTARELLA C, RIZZO F, ET AL.: Direct regulation of microRNA biogenesis and expression by estrogen receptor beta in hormone-responsive breast cancer. Oncogene 31: 4196-4206, 2012.

PELTIER HI, LATHAM J: Normalization of microRNA expression levels in quantitative RT-PCR assays: Identification of suitable reference RNA targets in normal and cancerous human solid tissues. RNA 14: 844-852, 2008.

PINK RC, SAMUEL P, MASSA D, CALEY DP, BROOKS SA, CARTER DR: The passenger strand, miR-21-3p, plays a role in mediating cisplatin resistance in ovarian cancer cells. Gynecol Oncol 137: 143-151, 2015.

PINTO R, DE SUMMA S, DANZA K, POPESCU O, PARADISO A, MICALE L, MERLA G, PALUMBO O, CARELLA M, TOMMASI S: MicroRNA expression profiling in male and female familial breast cancer. Br J Cancer 111: 2361-2368, 2014.

QIAN J, JIANG B, LI M, CHEN J, FANG M: Prognostic significance of microrna-16 expression in human colorectal cancer. World J Surg 37: 2944-2949, 2013.

RO S, PARK CH, YOUNG D, SANDERS KM, YAN W: Tissue-dependent paired expression of miRNAs. Nucleic Acids Res 35: 5944-5953, 2007.

SAYED D, RANE S, LYPOWY J, HE M, CHEN IY, VASHISTHA H, YAN L, MALHOTRA A, VATNER D, ABDELLATIF M: MicroRNA-21 targets Sprouty 2 and promotes cellular outgrowths. Mol Biol Cell 19: 3272-3282, 2008.

SLABY O, SVOBODA M, FABIAN P, SMERDOVA D, KNOFLICKOVA D, BEDNARIKOVA M, NENUTIL R, VYZULA R: Altered expression of miR-21, miR-31, miR-143 and miR-145 is related to clinicopathologic features of colorectal cancer. Oncology 72: 397-402, 2007.

SONG J, BAI Z, HAN W, ZHANG J, MENG H, BI J, MA X, HAN S, ZHANG Z: Identification of suitable reference genes for qPCR analysis of serum microRNA in gastric cancer patients. Dig Dis Sci 57: 897-904, 2012. 
TREIBER T, TREIBER N, MEISTER G: Regulation of microRNA biogenesis and function. Thromb Haemost 107: 605-610, 2012.

TORRE LA, BRAY F, SIEGEL RL, FERLAY J, LORTET-TIEULENT J, JEMAL A: Global cancer statistics, 2012. CA Cancer J Clin 65: 87-108, 2015.

VOGELSTEIN B, FEARON ER, HAMILTON SR, KERN SE, PREISINGER AC, LEPPERT M, NAKAMURA Y, WHITE R, SMITS AM, BOS JL: Genetic alterations during colorectal-tumor development. $N$ Engl J Med 319: 525-532, 1988.

VOGLOVA K, BEZAKOVA J, HERICHOVA I: Progress in micro RNA focused research in endocrinology. Endocr Regul 50: 83-105, 2016.

XIAO G, TANG H, WEI W, LI J, JI L, GE J: Aberrant expression of microRNA-15a and microRNA-16 synergistically associates with tumor progression and prognosis in patients with colorectal cancer. Gastroenterol Res Pract 2014: 364549, 2014.

YOU C, LIANG H, SUN W, LI J, LIU Y, FAN Q, ZHANG H, YUE X1, LI J, CHEN X, BA Y: Deregulation of the miR-16-KRAS axis promotes colorectal cancer. Sci Rep 6: 37459, 2016.

ZHANG X, WAN G, MLOTSHWA S, VANCE V, BERGER FG, CHEN H, LU X: Oncogenic Wip1 phosphatase is inhibited by miR-16 in the DNA damage signaling pathway. Cancer Res 70: 7176-86, 2010.

ZHU HT, DONG QZ, WANG G, ZHOU HJ, REN N, JIA HL, YE QH, QIN LX: Identification of suitable reference genes for qRT-PCR analysis of circulating microRNAs in hepatitis B virus-infected patients. Mol Biotechnol 50: 49-56, 2012. 